\title{
Evaluasi Tingkat Kelelahan pada Pengemudi Bus di Kota Bandung
}

\author{
Asterina Febrianti ${ }^{1}$, Yassierli ${ }^{2}$, Manik Mahachandra ${ }^{3}$ \\ ${ }^{1)}$ Fakultas Teknologi Industri Jurusan Teknik Industri Institut Teknologi Nasional \\ ${ }^{2,3)}$ Fakultas Teknologi Industri Jurusan Teknik dan Manajemen Industri Institut Teknologi Bandung \\ 1) Jl. Penghulu K.H. Hasan Mustafa No. 23 Bandung 40124 \\ 2) Jl. Ganesha No. 10 Bandung 40132
}

Email: febrianti.asterina@gmail.com ${ }^{1}$, yassierli@mail.ti.ttb.ac.id ${ }^{2}$, mahachandra@mail.ti.itb.ac.id ${ }^{3}$

\begin{abstract}
Abstrak
Kota Bandung saat ini mengalami pertumbuhan penduduk mencapai $3 \%$ setiap tahunnya, sehingga kebutuhan akan transportasi umum sangat tinggi serta tingkat kemacetan yang timbul semakin tinggi pula. Kemacetan yang panjang berdampak pada penurunan kewaspadaan dan timbulnya risiko kecelakaan karena waktu berkendara yang relatif lebih beragam. Menyadari akan risiko kecelakaan yang diakibatkan oleh kelelahan maka diperlukan pengukuran kelelahan pada pengemudi bus di kota Bandung yang belum pernah dikaji. Penggunaan alat ukur untuk mendeteksi kelelahan saat ini sangat beragam sehingga diperlukan alat ukur terbaik untuk mendeteksi kelelahan pengemudi bus di kota Bandung. Pengukuran kelelahan menggunakan indikator variabilitas denyut jantung dengan menggunakan alat Polar RS800CX (RMSSD dan LF/HF) dan skala tingkat kelelahan dengan kuesioner Visual Analog Scale (VAS). Kuesioner VAS menunjukkan sebanyak 29,9\% pengemudi bus Damri mengalami peningkatan kondisi kelelahan dan Polar RS800CX menunjukkan $46 \%$ peningkatan kondisi kelelahan. Kriteria selang interval waktu berkendara menunjukkan hasil yang signifikan. Pada penelitian ini, kuesioner VAS mampu mendeteksi kelelahan dibanding alat ukur Polar RS800CX. Korelasi alat ukur antara kuesioner VAS dengan Polar RS800CX (parameter rasio LF/HF) sebesar 0.025 yang menunjukkan nilai signifikan dan kedua alat tersebut mempunyai kekuatan yang sama dalam mengukur kelelahan. Setengah set data pengemudi menunjukkan peningkatan kondisi kelelahan interval waktu berkendara 2 hingga 2,5 jam sehingga pemberlakuan jam istirahat pada waktu tertentu setelah mengemudi selama 1 ritase sangat dianjurkan. Jam kerja yang tidak berimbang antara waktu mengemudi pagi dan siang berpontensi timbulnya peningkatan kondisi kelelahan sehingga pihak Damri sebaiknya mengkaji ulang pembagian waktu mengemudi.
\end{abstract}

Kata kunci: Pengemudi Bus, Kewaspadaan, Kelelahan, RMSSD, rasio LF/HF, VAS.

\section{Pendahuluan}

Pemerintah kota Bandung melalui kepala daerahnya memiliki visi menciptakan Bandung yang aman, nyaman, dan unggul. Pencapaian visi tersebut didukung dengan salah satu misinya adalah nyaman melalui tata ruang dan pembangunan infrastruktur serta pengendalian pemanfaatan ruang yang berkualitas dan berwawasan lingkungan. Kota Bandung melalui Renstra 2013-2018 saat ini sedang mengalami pertumbuhan penduduk mencapai $3 \%$ setiap tahunnya, sehingga kebutuhan akan transportasi umum sangat tinggi disertai tingkat kemacetan yang timbul semakin tinggi pula. Kemacetan yang panjang berdampak pada penurunan kewaspadaan dan timbulnya risiko kecelakaan karena waktu berkendara yang relatif lebih beragam. Dinas Perhubungan kota Bandung bersama dengan Perum Damri saat ini sedang meningkatkan kenyamanan pengguna sarana transportasi bus di kota Bandung. Ketika pengemudi berkendara secara terus menerus, pekerjaan tersebut akan bersifat monoton dan pada umumnya tingkat kewaspadaan akan menurun (Pastor et al., 2006). Penurunan kewaspadaan dapat mempengaruhi kondisi kelelahan dalam berkendara (Lal \& Craig, 2001).

Kelelahan sering dikaitkan dengan kecelakaan saat berkendara. Hubungan antara kelelahan dan keselamatan belum terlihat secara signifikan (Williamson et al., 2011). Banyak faktor yang menimbulkan kelelahan dan berhubungan dengan kecelakaan, jam sibuk di pagi hari merupakan salah satu faktor risiko kelelahan yang menimbulkan kecelakaan namun tidak menimbulkan korban jiwa yang parah (Zang et al., 2016). Berdasarkan penelitian tentang kelelahan dan kondisi yang terjadi saat ini, maka kelelahan merupakan masalah yang perlu ditinjau lebih lanjut untuk mengetahui dampaknya pada pengemudi bus dalam kota yaitu bus Damri selama I ritase.

Kelelahan dibagi menjadi 2 jenis yaitu kelelahan fisik dan kelelahan mental (Lal \& Craig, 2001). Kelelahan fisik erat dengan kondisi fisiologis setiap individu sedangkan kelelahan mental erat dengan perasaan yang dirasakan oleh setiap individu. Saat ini terdapat berbagai macam alat ukur kelelahan, namun belum ada alat ukur terbaik yang dapat mengidentifikasi kelelahan. Terdapat beberapa alat yang dapat digunakan untuk mengevaluasi 
kelelahan dalam berkendara, salah satunya pengukuran fisiologis yaitu dengan pengukuran aktivitas denyut jantung. Pengukuran persepsi atau secara subjektif menggunakan kuesioner Visual Analog Scale (VAS) merupakan alat pengukuran yang valid dan reliabel untuk penilaian secara kuantitatif pada kelelahan dan tingkat kekuatannya sangat baik untuk digunakan pada subjek yang sehat dan pasien yang memiliki masalah dengan waktu tidur (Lee et al., 1990).

Sebuah penelitian menyatakan terdapat penurunan yang signifikan pada aktivitas denyut jantung saat mengalami kondisi kelelahan berkendara (Lal \& Craig, 2001). Perubahan variabilitas denyut jantung (HRV) dan kondisi kelelahan berhubungan dengan penurunan kondisi kewaspadaan saat berkendara (Lal \& Craig, 2001). Parameter yang dapat digunakan untuk mengukur perubahan tingkat kelelahan ialah rasio LF/HF (low frequency/high frequency) (Patel et al., 2011). Selain itu, parameter RMSSD (root mean square successive difference) merupakan pengukuran aktivitas otonom yang mengatur saat terjadinya kondisi kelelahan (Mahachandra et al., 2012). Parameter dari indikator persepsi berupa garis pada kuesioner VAS sangat mudah di pahami oleh subjek yang mengisinya dan hanya membutuhkan kemampuan membaca yang cukup minim (Lee et al., 1990).

Perum Damri saat ini perlu memonitor tingkat kelelahan pengemudi bus dalam berkendara untuk mengurasi risiko kecelakaan. Sampai saat ini belum ada pengkajian secara ilmiah terhadap pengemudi bus di kota Bandung. Tujuan penelitian ini adalah untuk mengevaluasi tingkat kelelahan pengemudi bus di kota Bandung serta untuk mengetahui alat ukur terbaik untuk mendeteksi kelelahan. Oleh karena itu, diperlukan pengukuran kelelahan pada pengemudi bus di kota Bandung dengan melihat indikator variabilitas denyut jantung dan indikator persepsi skala tingkat kelelahan.

\section{Studi Literatur}

\section{Definisi Ergonomi}

Ergonomi yang dikemukakan oleh beberapa ahli memiliki pemaparan sebagai berikut :

1. Sutalaksana et al. (1979) menjelaskan nama 'ergonomics' berasal dari bahasa yunani 'ergon', yang berarti kerja dan 'nomos' yang berarti hukum. Dengan demikian ergonomi dimaksudkan sebagai disiplin keilmuan yang mempelajari manusia dalam kaitannya dengan pekerjaannya. Maksud dan tujuan dari disiplin ergonomi adalah mendapatkan suatu pengetahuan yang utuh tentang permasalahan-permasalahan interaksi manusia dengan teknologi dan produkproduknya, sehingga memungkinkan adanya suatu rancangan sistem manusiamanusia (teknologi) yang optimal. Dengan demikian disiplin ergonomi melihat permasalahan interaksi tersebut sebagai suatu sistem dengan pemecahanpemecahan masalahnya melalui proses pendekatan sistem pula.

2. Nurmianto (1998) menjelaskan istilah "ergonomi" berasal dari bahasa latin yaitu ergon (kerja) dan nomos (hukum alam) dan dapat didefinisikan sebagai studi tentang aspek-aspek manusia dalam lingkungan kerjanya yang ditinjau secara anatomi, fisiologi, psikologi, engineering, manajemen dan desain/perancangan.

3. Bridger (2003) menjelaskan bahwa ergonomi adalah ilmu yang mempelajari interaksi antara orang dan mesin dan faktor-faktor yang mempengaruhi interaksi tersebut. Tujuannya adalah untuk meningkatkan performansi dari sistem dengan cara meningkatkan interaksi antara manusia dan mesin. Hal tersebut dapat dicapai dengan cara merancang alat penghubung yang lebih baik atau merancang faktor yang terdapat pada lingkungan kerja, di setiap pekerjaan atau di setiap organisasi kerja yang dapat menurunkan performansi manusia mesin.

4. Iridiastadi \& Yassierli (2014) mendefinisikan ergonomi sebagai suatu disiplin yang mengkaji keterbatasan, kelebihan, serta karakteristik manusia, dan memanfaatkan informasi tersebut dalam merancang produk, mesin, fasilitas, lingkungan, dan bahkan sistem kerja, dengan tujuan utama tercapainya kualitas kerja yang terbaik tanpa mengabaikan aspek kesehatan, keselamatan, serta kenyamanan manusia penggunanya. Tujuan utama yang hendak dicapai adalah tercapaianya sistem kerja yang produktif dan kualitas kerja terbaik, disertai dengan kemudahan, kenyamanan, dan efisiensi kerja, tanpa mengabaikan kesehatan dan keselamatan kerja.

\section{Ergonomi Berkendara}

Berkendara secara terus menerus dengan jadwal berkendara yang tidak teratur dapat menimbulkan kelelahan berkendara baik pada pengemudi komersial (Chen \& Xie, 2014). Interaksi manusia terhadap lingkungannya dapat menimbulkan keterbatasan pada manusia itu sendiri. Kelelahan berkendara merupakan keterbatasan manusia yang perlu dikaji dari sebuah sistem kerja tujuannya ialah meningkatkan kualitas kerja terbaik pengemudi dalam berkendara. Oleh karena itu, diperlukan perancangan sistem kerja yang dapat meningkatkan kualitas kerja dari pengemudi. 


\section{Fisiologi Kerja}

Beberapa faktor yang mempengaruhi kemampuan manusia dalam aktivitas kerja fisik menurut Rodahl (2005) diantaranya ialah jenis kelamin, kelelahan, pekerjaan yang bersifat terus-menerus, dan jadwal bekerja.

1. Jenis kelamin

Terdapat perbedaan antara pria dan wanita khususnya yang melibatkan aktivitas fisik. Pria lebih baik dari wanita dalam ketajaman pengelihatan. Seiring bertambahnya usia kekuatan otot pada pria lebih kuat dibandingkan wanita sehingga dalam aktivitas fisik pria lebih dominan dibanding wanita.

2. Kelelahan

Perasaan subjektif dari kelelahan biasa muncul saat diakhir bekerja dengan durasi selama 8 jam disaat rata-rata beban kerja sudah melebihi $30-40 \%$ dari kapasitas kerja maksimal dari setiap individu, tergantung pada pekerjaannya bersifat terus menerus atau berselang.

3. Pekerjaan yang bersifat terus-menerus

Beban kerja submaksimal, makanan yang dikonsumsi setiap individu dapat menahan 6 jam kerja (15 menit istirahat setiap per jam kerja) pada beban yang sesuai ratarata 60 persen setiap penyerapan tanpa mengalami masalah. Bekerja secara terus menerus dapat menimbulkan gejala sistem saraf pusat dari hipoglikemia (pusing, mual, bingung, hilang kesadaran, dll.)

4. Work schedule (jadwal kerja)

Beberapa orang performansinya lebih baik di awal hari (Tipe A), sementara individu lainnya memiliki performansi lebih di kondisi sebaliknya (Tipe B) dan hal ini berkaitan dengan irama sirkadian atau jam operasi biologis individu. Perbedaan waktu mengemudi seperti waktu mengemudi pagi dan waktu mengemudi malam sangat mempengaruhi performansi dalam bekerja khususnya untuk waktu mengemudi malam jika memiliki kondisi Tipe A maka jam operasi biologisnya akan terganggu.

\section{Kelelahan}

Kelelahan merupakan salah satu faktor yang mempengaruhi aktivitas kerja fisik. Definisi kelelahan yang diungkapkan beberapa ahli ialah sebagai berikut.

1. Menurut Bridger (2003) terdapat 3 perbedaan pengertian mengenai kelelahan. Terkadang digunakan untuk mengartikan kantuk, kelelahan adalah kehilangan kantuk atau gangguan terhadap irama sirkadian. Dikatakan juga memiliki persamaan dengan istilah "tiredness" (sebagai contoh setelah melakukan lari maraton atau mengangkat beban yang berat).
2. Ream dan Richardson (1996 dalam Bridger, 2003), menunjukkan definisi bahwa kelelahan adalah gejala subjektif yang tidak menyenangkan dan mencakup perasaan tubuh mulai dari tiredness hingga exhaustion, menciptakan kondisi ini secara keseluruhan tak henti-hentinya mengganggu kemampuan individu untuk berfungsi dalam kapasitas normal.

3. Lal \& Craig (2001) mengungkapkan bahwa kelelahan adalah waktu peralihan antara kondisi sadar dan kondisi tertidur, jika tidak diganggu dapat mengantarkan pada kondisi tertidur.

4. Grandjean (1988 dalam Lal \& Craig, 2001) mendefinisikan istilah kelelahan adalah pengurangan efisiensi dan keengganan untuk melakukan pekerjaan.

5. Philip et al. (2005) mendefinisikan bahwa kelelahan biasanya terlihat sebagai kondisi bertahap dan berakumulasi karena aktivitas yang berkelanjutan dan berhubungan dengan keengganan melakukan suatu usaha dan mengakibatkan performansi yang tidak efisien.

\section{Kelelahan Berkendara}

Williamson et al. (1996 dalam Lal \& Craig, 2001) mendefinisikan bahwa kelelahan berkendara adalah kondisi penurunan kewaspadaan, dimana dapat menganggu performansi dari pekerjaan yang melibatkan aspek kognitif dan psikomotor, dan termasuk salah satunya adalah mengemudi. Brown (1994 dalam Lal \& Craig, 2001) menyimpulkan bahwa kelelahan berkendara sebagian besar disebabkan oleh waktu kerja yang berpepanjangan dan tidak teratur. Mackie dan Miller (1978 dalam Lal \& Craig, 2001) mengulas bahwa kelelahan berkendara pada pengemudi bus dan truk disebabkan oleh jadwal berkendara yang tidak teratur dan dapat mengakibatkan kelelahan yang bersifat subjektif, stress fisik, dan penurunan performansi dibandingkan dengan jadwal berkendara yang teratur.

\section{Metode Pengukuran Kelelahan}

Kelelahan dibedakan menjadi kelelahan fisik dan mental sehingga pengukuran kelelahan perlu dilakukan secara terpisah. Kelelahan fisik berhubungan dengan pengukuran objektif karena erat kaitannya dengan kondisi fisiologis. Sedangkan kelelahan mental berhubungan dengan pengukuran subjektif karena erat kaitannya perasaan yang dirasakan oleh setiap individu.

\section{Pengukuran Objektif}

Denyut jantung sering digunakan sebagai pengukuran fisiologis khususnya dalam kondisi saat berkendara ( $\mathrm{Lal}, 2001)$. Riemersma et al. (1977 dalam Lal, 2001) menjelaskan 
variabilitas denyut jantung dan kelelahan berhubungan dengan penurunan kondisi saat berkendara. Variabilitas denyut jantung atau heart rate variability (HRV) merupakan variasi dari detak jantung dan dihitung dengan cara menganalisis interval waktu antar detak jantung (Patel et.al, 2011). HRV dapat diukur dengan berbasis time domain analysis dan frequency domain analysis (Ferri et al., 1998). Menurut Hartono et al. (2013) parameter analisis HRV berbasis time domain diantara ialah sebagai berikut.

1. NN yaitu jumlah dari $\mathrm{R}-\mathrm{R}$ interval

2. NN50 yaitu jumlah dari R-R interval yang lebih dari $50 \mathrm{~ms}$

3. pNN50 yaitu perbandingan NN50 dengan semua jumlah NN

4. RMSSD yaitu akar kuadrat dari rerata kuadrat perbedaan NN interval yang berturut-turut

Sementara pengukuran HRV berbasis frequency domain berdasarkan transformasi matematika (fast fourier transforms) dari sinyal yang berasal dari time domain menuju frequency domain (dinyatakan dengan siklus per denyut dengan amplitudo dan frekuensi yang berganti-ganti) (Patel et al., 2011). Analisis power spectral density (PSD) memberikan informasi dasar tentang bagaimana power disebarkan sebagai fungsi dari frekuensi (Patel et al., 2011). Ferri dkk. (1998) menyatakan bahwa high frequency (HF) memiliki kontribusi utama pada aktivitas saraf vagus sedangkan low frequency (LF) ditinjau oleh peneliti sebagai tanda modulasi simpatetik dan oleh peneliti lainnya terkadang sebagai parameter yang termasuk didalamnya memiliki pengaruh saraf vagus dan simpatetik.

\section{Pengukuran Subjektif}

VAS berguna untuk menilai kelelahan otot yang meluas pada kondisi beban kerja yang rendah dan akan sensitif jika terdapat perasaan subjektif yang berbeda (Leung et al., 2004). Garis dalam VAS tidak membatasi subjek untuk berubah-ubah, seperti nilai yang paling tinggi mengindikasikan respon positif dan nilai paling rendah mengindikasikan respon negatif (Lee et al., 1990). Menurut Lee et al. (1990) VAS merupakan alat pengukuran yang valid dan reliabel untuk penelitian secara kuantitatif pada kelelahan dan tingkat kekuatan yang lebih baik untuk subjek yang sehat dan yang memiliki masalah dengan kurangnya waktu tidur.

\section{Kemiringan Parameter Kelelahan}

Secara matematis slope atau kemiringan merupakan koefisien regresi yang dapat menunjukkan pola atau kecenderungan suatu data. Pada pengukuran kelelahan kemiringan suatu data dapat dijadikan indikator perubahan atau peningkatan kondisi kelelahan.
Kemiringan berasal dari nilai PSD untuk parameter rasio LF/HF. Arti kemiringan suatu pola data bergantung pada parameter kelelahan yang digunakan. Berikut ini terdapat beberapa penelitian yang menjadi indikator dalam penentuan kondisi kelelahan.

1. Mahachandra et al. (2012) menjelaskan bahwa penurunan nilai RMSSD disertai dengan peningkatan kondisi kelelahan.

2. Patel et al. (2011) menjelaskan penurunan nilai rasio LF/HF seiring dengan peningkatan kondisi kelelahan.

3. Insana et al. (2010) Skala VAS dalam mengukur kelelahan yang bersifat single item dapat berupa "seberapa lelah yang kamu rasakan saat ini?" (0 = tidak lelah sama sekali, 100 = sangat lelah).

\section{Metodologi Penelitian}

Objek penelitian ialah pengemudi Bus Damri kota Bandung. Observasi awal dilakukan pada pengemudi Bus Damri dengan rute perjalanan Leuwipanjang-Cicaheum dan Leuwipanjang-Dago. Faktor demografi berupa usia, waktu mengemudi, dan selang interval waktu berkendara menjadi kriteria dalam penelitian ini. Kedua rute ini dipilih karena memiliki kondisi armada yang cukup baik yang dapat menunjang penggunaan alat-alat penelitian serta kesiapan dari pihak Damri tersendiri. Masing-masing kriteria akan dikaji untuk melihat perbedaan kelelahan yang terjadi pada pengemudi Bus Damri.

Partisipan merupakan 20 orang laki-laki pengemudi aktif bus kota. Rute yang dipilih adalah Leuwipanjang-Cicaheum dan Leuwipanjang-dago berdasarkan armada bus yang tersedia. Rentang usia berkisar antara 15-64 tahun dan dinyatakan sebagai rentang usia produktif (Nurhasikin, 2013). Pengalaman mengemudi kisaran 1-2 tahun dengan alasan pengemudi sudah melampaui kurva belajar dalam mengemudi, serta memiliki sim khusus kendaraan Bus kota. Pengemudi Bus kota merupakan pengemudi dari Djawatan Angkoetan Motor Repoeblik Indoenesia (Damri) di Bandung. Pembagian waktu mengemudi dari pukul 06.00-12.00 untuk waktu pagi dan pukul 12.00-18.00 untuk waktu siang. Dasar penentuan waktu mengemudi berdasarkan irama sirkadian yang berhubungan dengan jam biologis tubuh manusia. Teknik pengambilan sampel partisipan dalam penelitian ini adalah convenience sampling (non probabilistic sampling).

\section{Variabel Penelitian}

Kelelahan menurut beberapa penelitan sangat berkontribusi meningkatkan risiko kecelakaan dan konsep mengenai kelelahan dapat dilihat pada Gambar 1. Kelelahan terjadi karena 
adanya penurunan kewaspadaan. Penurunan kewaspadaan dipengaruhi oleh faktor internal dan eksternal. Mengemudi merupakan jenis pekerjaan yang melibatkan faktor internal usia, irama sirkadian, dan waktu tidur, sementara faktor eksternal berupa waktu mengemudi dan durasi kerja. Untuk mengurangi risiko kecelakaan dalam berkendara maka diperlukan pengukuran terhadap kondisi kelelahan pengemudi. Pengukuran kelelahan dapat menggunakan indikator fisiologis dan indikator persepsi.

Mengacu pada Gambar 1 variabel dalam penelitian ini yaitu variabel Independen berupa kriteria selang interval waktu berkendara, usia, dan waktu mengemudi pengemudi bus. Variabel dependen pada penelitian ini berupa kelelahan pengemudi Bus dalam berkendara. Variabel kontrol dalam penelitian ini adalah jenis kelamin pengemudi yaitu laki-laki. Jenis kelamin disamakan agar aktivitas fisik yang dihasilkan oleh setiap pengemudi sama untuk setiap kondisi berkendara.

\section{Alat Penelitian}

Penelitian dilakukan dengan cara mendatangi para pengemudi bus dan melakukan penelitian secara langsung saat pengemudi sedang berkendara tanpa adanya intervensi. Alat yang digunakan pada pengukuran kelelahan ialah:

1. Polar RS800CX training computer

Polar RS800CX berfungsi mengukur variabilitas denyut jantung (HRV). Perubahan HRV dan kondisi kelelahan berhubungan dengan penurunan kondisi berkendara (Harris et al.,1972 dalam Lal \& Craig, 2001). Penurunan kondisi berkendara merupakan tanda pengurangan kewaspadaan (Lal \& Craig, 2001). Perubahan denyut jantung memiliki potensi yang sangat besar dalam menimbulkan kelelahan berkendara (Hartley \& Arnold, 1994 dalam Lal \& Craig, 2001).

2. Kuesioner Visual Analog Scale (VAS)

Merupakan alat pengukuran subjektif yang berguna untuk mengukur kelelahan yang dirasakan setiap pengemudi. VAS memiliki keunggulan dibandingkan dengan pengukuran subjektif lainnya seperti Karolinska Sleepiness Scale (KSS) atau Standford Sleepiness Scale (SSS) yaitu sangat mudah dimengerti dan mudah untuk dibaca, mudah diatur dan waktu pengisian tidak lama, karena waktu yang sebentar untuk melengkapi VAS maka tidak akan kekurangan data, bias yang ditimbulkan kecil, dan skala VAS dengan item yang banyak lebih stabil dalam mengukur kelelahan dibanding dengan SSS yang memiliki single item (Lee et al., 1990).

\section{Parameter Kelelahan}

1. Time Domain Analysis

Pengukuran HRV berbasis time domain paling sering dan mudah digunakan serta penilaian dapat dilakukan dengan perhitungan standar deviasi dari interval antar denyut jantung ( $R$ - $R$ interval) (Patel et al., 2011). Menurut Hartono et al. (2013) parameter analisis HRV salah satunya ialah RMSSD yaitu akar kuadrat dari rerata kuadrat perbedaan NN interval yang berturut-turut.

\section{Frequency Domain Analysis}

Terdapat 4 komponen utama yang diperoleh dari kekuatan spektrum detak jantung Ultra low frequency $(0.0-0.0033)$, Very low frequency (0.0033-0.04), Low Frequency (0.04-0.15), dan High Frequency (0.15-0.40) (Patel et al., 2011). High frequency (HF) memiliki kontribusi utama pada aktivitas saraf vagus sedangkan low frequency (LF) ditinjau oleh peneliti sebagai tanda modulasi simpatetik dan oleh peneliti lainnya terkadang sebagai parameter yang termasuk didalamnya memiliki pengaruh saraf vagus dan simpatetik (Ferri et al., 1998).

3. Kuesioner Tingkat Kelelahan

VAS memiliki nilai pengukuran dengan satuan millimeter $(\mathrm{mm})$ dari 0 hingga 100 (Jhonson et al., 1990). Tidak seperti penggunaan standford sleepiness scale (SSS) yang hanya bersifat single item, skala VAS dapat bersifat multiple item dan bersifat lebih stabil dalam pengukuran kelelahan (Lee et al., 1990). Menurut Insana et al. (2010) skala VAS dalam mengukur kelelahan yang bersifat single item dapat berupa "seberapa lelah yang kamu rasakan saat ini?" (0 = tidak lelah sama sekali, 100 = sangat lelah). Skala yang bersifat multiple item dapat berupa "sangat lelah" di sisi kiri dan "terjaga" di sisi kanan (Schneider et al., 2004). 


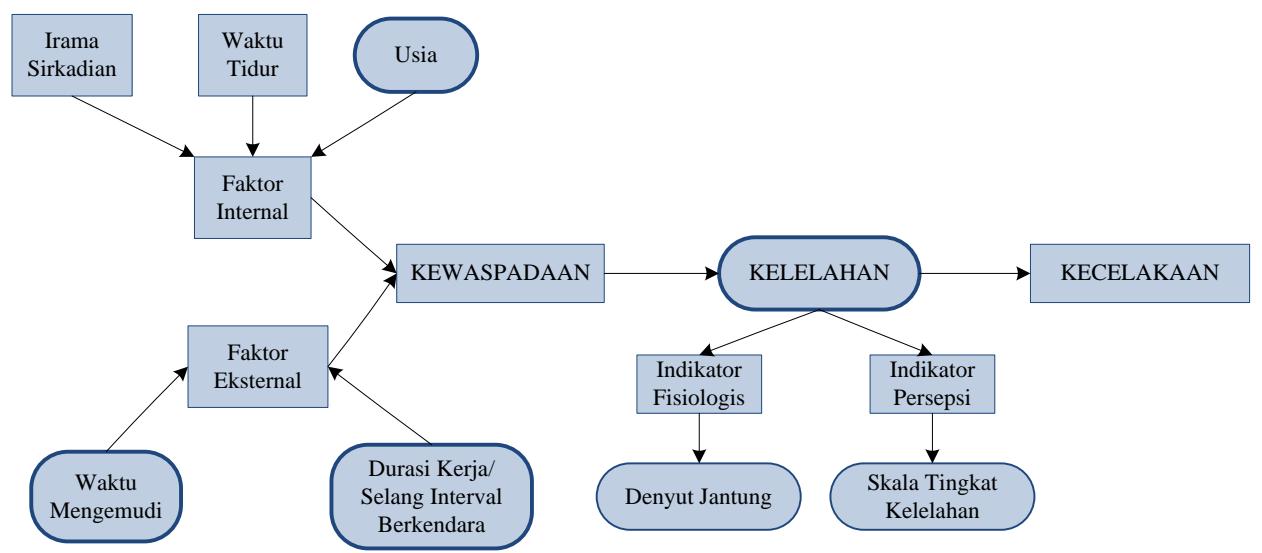

Gambar 1. Kerangka Berpikir

\section{Hasil dan Pembahasan}

\section{Pengolahan Data}

Data yang dikumpulkan berupa data rekaman dari alat Polar RS800CX dan data rekapitulasi kuesioner VAS. Pengujian dengan menggunakan uji statistik yaitu $U j i \mathrm{t}$, Uji UMann Whitney, dan Uji Kruskal-Wallis yang bertujuan untuk mengetahui perbedaan kelelahan yang terjadi pada setiap kriteria yang diuji. Uji korelasi bertujuan untuk melihat korelasi anatara parameter kelelahan yang diuji. Penggunaan $p$-value $<5 \%$ dengan alasan agar bias yang terjadi kecil dengan ukuran sampel yang kecil.

Data rekaman dari masing-masing alat ukur diolah berupa nilai slope atau kemiringan untuk masing-masing parameter kelelahan. Secara matematis slope atau kemiringan merupakan koefisien regresi yang dapat menunjukkan pola atau kecenderungan suatu data. Pada pengukuran kelelahan kemiringan suatu data dapat dijadikan indikator perubahan atau peningkatan kondisi kelelahan. Gambar 2 merupakan contoh pola kemiringan seorang partisipan yang menunjukkan parameter kelelahan RMSSD, rasio LF/HF, dan nilai VAS memiliki kecenderungan naik (kelelahan akan meningkat seiring dengan peningkatan nilai kemiringan).

Koefisien korelasi adalah ukuran untuk menentukan kuatnya hubungan linear antara variabelnya (Sudjana, 2004). Uji korelasi dilakukan pada setiap parameter kelelahan terhadap perubahan waktu saat mengemudi. Hasil menunjukkan masing-masing parameter kelelahan tidak signifikan terhadap perubahan waktu atau tidak terdapat korelasi antara masing-masing parameter kelelahan dengan selang interval waktu. Tidak adanya hubungan antara parameter dan selang interval waktu dapat disebabkan oleh adanya variabelvariabel lain yang mempengaruhi pengemudi dalam berkendara.

\section{Kriteria Selang Interval Waktu}

Presentasi nilai kemiringan (-) parameter RMSSD berdasarkan Tabel 1. secara keseluruhan menghasilkan persentase nilai kemiringan (-) sebesar 51,38\%. Artinya, adanya peningkatan kondisi kelelahan pada parameter rasio LF/HF. Persentase nilai kemiringan parameter VAS berdasarkan Tabel 1. secara keseluruhan menghasilkan persentase nilai kemiringan $(+)$ sebesar $29,9 \%$. Artinya, adanya peningkatan kondisi kelelahan pada parameter VAS.

\section{Kriteria Usia Partisipan}

Persentase nilai kemiringan (-) parameter RMSSD kelompok usia dibawah 45 tahun dan diatas 45 tahun sebesar $60 \%$ dan $50 \%$, secara teori pada kelompok usia tersebut pengemudi mengalami peningkatan kondisi kelelahan. Berdasarkan Tabel 2. secara keseluruhan menghasilkan persentase nilai kemiringan (-) sebesar $55 \%$. Artinya, terdapat peningkatan kondisi kelelahan yang signifikan pada parameter RMSSD kriteria usia partisipan.

Persentase nilai kemiringan (-) parameter rasio LF/HF kelompok usia dibawah 45 tahun dan diatas 45 tahun sebesar $60 \%$, secara teori pada kelompok usia tersebut pengemudi mengalami peningkatan kondisi kelelahan. Berdasarkan Tabel 2. secara keseluruhan menghasilkan persentase nilai kemiringan (-) sebesar $60 \%$. Artinya, terdapat peningkatan kondisi kelelahan yang signifikan pada parameter rasio LF/HF kriteria usia partisipan.

Persentase nilai kemiringan parameter VAS menunjukkan nilai $(+)$ untuk semua kelompok usia partisipan. Secara teori peningkatan nilai VAS akan disertai dengan peningkatan kondisi kelelahan. Berdasarkan Tabel 2. secara keseluruhan menghasilkan persentase nilai kemiringan $(+)$ sebesar $39,16 \%$. Artinya, adanya peningkatan kondisi kelelahan pada parameter VAS kriteria usia partisipan. 


\section{Kriteria Waktu Mengemudi}

Persentase nilai kemiringan (-) parameter RMSSD pada waktu mengemudi pagi dan waktu mengemudi siang sebesar $45 \%$ dan $53 \%$, secara teori pada kedua waktu mengemudi siang mengalami peningkatan kondisi kelelahan. Berdasarkan Tabel 3. secara keseluruhan menghasilkan persentase nilai kemiringan (-) sebesar $49 \%$. Artinya, tidak terdapat peningkatan kondisi kelelahan yang signifikan pada parameter RMSSD kriteria waktu mengemudi.

Persentase nilai kemiringan (-) parameter rasio LF/HF pada waktu mengemudi pagi dan waktu mengemudi siang sebesar $35 \%$ dan $60 \%$, secara teori waktu mengemudi siang mengalami peningkatan kondisi kelelahan. Berdasarkan Tabel 3. secara keseluruhan menghasilkan persentase nilai kemiringan (-) sebesar $46 \%$. Artinya, tidak terdapat peningkatan kondisi kelelahan yang signifikan pada parameter rasio LF/HF kriteria waktu mengemudi.

Persentase nilai kemiringan parameter VAS menunjukkan nilai $(+)$ untuk semua waktu mengemudi. Secara teori peningkatan nilai VAS akan disertai dengan peningkatan kondisi kelelahan. Berdasarkan Tabel 3. secara keseluruhan menghasilkan persentase nilai kemiringan (+) sebesar $39,16 \%$. Artinya, adanya peningkatan kondisi kelelahan pada parameter VAS kriteria waktu mengemudi.

\section{Pengujian Parameter Kelelahan}

Parameter RMSSD dengan kriteria selang interval waktu berkendara, usia partisipan, dan waktu mengemudi pada Tabel 4. menghasilkan nilai signifikansi sebesar 0,725, 0,548, dan 0,605. Parameter rasio LF/HF dengan kriteria selang interval waktu berkendara, usia partisipan, dan waktu mengemudi pada Tabel 4. menghasilkan nilai signifikansi sebesar 0,518, 0,648, dan 0,080. Parameter RMSSD dan rasio LF/HF menunjukkan tidak terdapat perbedaan ratarata kelelahan yang signifikan pada masing- masing kriterianya. Artinya, parameter RMSSD dan Rasio LF/HF tidak signifikan dalam mendeteksi kelelahan pengemudi saat berkendara.

Pengolahan data secara subjektif dengan parameter VAS pada Tabel 4. menghasilkan nilai signifikansi sebesar 0,006 untuk kriteria selang interval waktu berkendara, sedangkan untuk kriteria usia partisipan dan waktu mengemudi menghasilkan nilai signifikansi sebesar 0,339 dan 0,200. Berdasarkan hasil tersebut maka parameter VAS signifikan dalam mendeteksi kelelahan pengemudi saat berkendara dengan kriteria selang interval waktu berkendara. Hasil uji post hoc yang dapat dilihat pada Tabel 1, hasil menunjukkan peningkatan kondisi kelelahan terjadi pada selang interval 2-2,5 jam berkendara dengan kenaikan sebesar $29,9 \%$.

Hasil dari ketiga parameter kelelahan menunjukkan bahwa kuesioner VAS paling signifikan dalam mendeteksi kelelahan pengemudi bus Damri. Alat ukur Polar RS800CX yang digunakan tidak signifikan dalam mendeteksi kelelahan pengemudi Bus. Pengukuran secara fisiologis yang dipaparkan oleh peneliti dianggap sudah paling reliabel dalam mendeteksi kelelahan sehingga dalam hal ini dibutuhkan validasi lebih lanjut mengenai pengukuran kelelahan dari sisi persepsi diri seseorang atau secara subjektif.

\section{Uji Korelasi antar Parameter dan Perubahan Waktu Berkendara}

Uji interkorelasi dilakukan untuk mengetahui korelasi antar parameter yang digunakan dalam mendeteksi kelelahan. Hasil menunjukkan bahwa parameter rasio LF/HF dan parameter VAS berkorelasi positif dengan nilai signifikansi 0,025. Artinya alat ukur Kuesioner VAS dan Polar RS800CX memiliki kekuatan yang sama dalam mendeteksi kelelahan. Penggunaan salah satu alat ukur sangat dianjurkan untuk memudahkan pengukuran kelelahan.

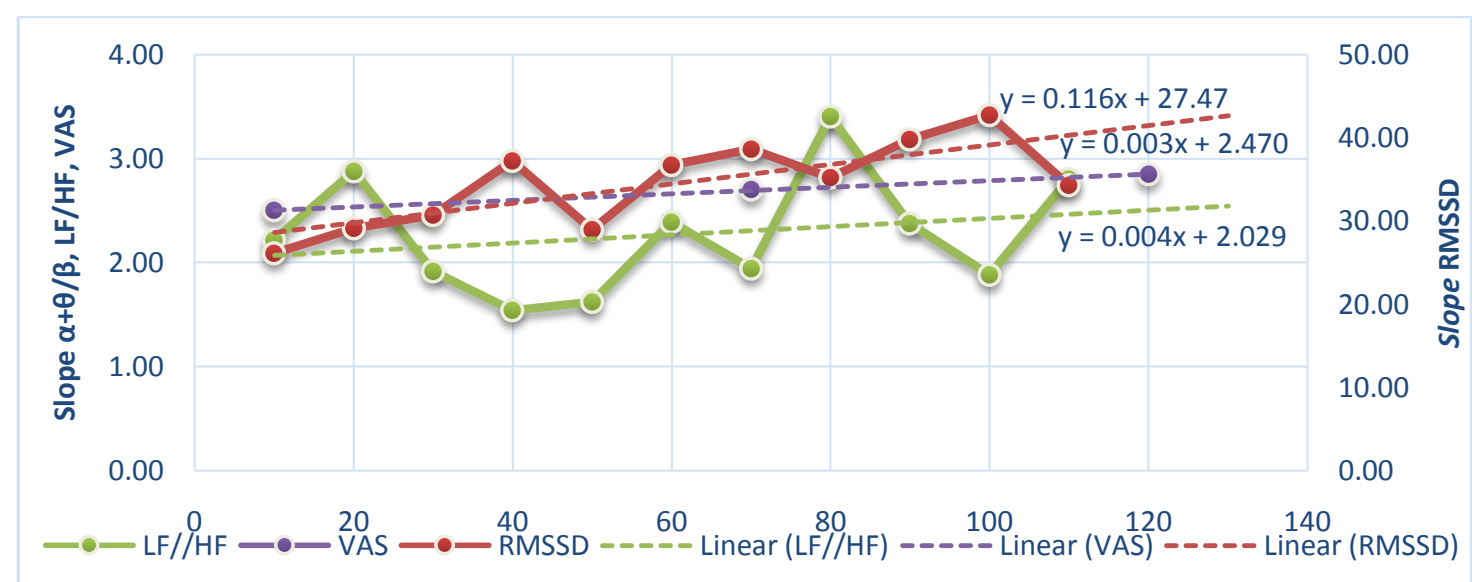

Gambar 2. Contoh Pola Kemiringan Parameter Kelelahan dari Seorang Partisipan 
Tabel 1. Rekapitulasi parameter kelelahan kriteria selang interval waktu

\begin{tabular}{lcccc}
\hline \multirow{2}{*}{ Parameter } & \multicolumn{2}{c}{ Kemiringan } & Hasil uji beda selang interval & Hasil uji post hoc \\
\cline { 2 - 4 } & $(+)$ & $(-)$ & & \\
\hline RMSSD & $49.54 \%$ & $50.46 \%$ & Tidak signifikan (p-value $=0.725)$ & - \\
\hline Rasio LF/HF & $48.62 \%$ & $51.38 \%$ & Tidak signifikan $(p-v a l u e=0.518)$ & Sig. antara 0-0.5 jam \& 1-1.5 jam \\
\hline VAS & $29.9 \%$ & - & Signifikan (p-value $=0.006)$ & Sig. antara 0-0.5 jam \& 2-2.5 jam \\
& & & & Sig. antara 0.5-1 jam \& 2-2.5 jam \\
& & & & Sig. antara 1-1.5 jam \& 2-2.5 jam \\
\hline
\end{tabular}

Tabel 2. Rekapitulasi Parameter Kelelahan Kriteria Usia Partisipan

\begin{tabular}{lccc}
\hline \multirow{2}{*}{ Parameter } & \multicolumn{2}{c}{ Kemiringan } & Hasil uji beda usia partisipan \\
\cline { 2 - 3 } & $(+)$ & $(-)$ & \\
\hline RMSSD & $45 \%$ & $55 \%$ & Tidak signifikan (p-value $=0.548)$ \\
\hline Rasio LF/HF & $40 \%$ & $60 \%$ & Tidak signifikan ( $\mathrm{p}$-value $=0.648)$ \\
\hline VAS & $39.16 \%$ & - & Tidak signifikan $(\mathrm{p}$-value $=0.339)$ \\
\hline
\end{tabular}

Tabel 3. Rekapitulasi Parameter Kelelahan Kriteria Waktu Mengemudi

\begin{tabular}{lccc}
\hline \multirow{2}{*}{ Parameter } & \multicolumn{2}{c}{ Kemiringan } & Hasil uji beda waktu mengemudi \\
\cline { 2 - 3 } & $(+)$ & $(-)$ & \\
\hline RMSSD & $51 \%$ & $49 \%$ & Tidak signifikan (p-value $=0.605)$ \\
\hline Rasio LF/HF & $54 \%$ & $46 \%$ & Tidak signifikan (p-value $=0.080)$ \\
\hline VAS & $39.16 \%$ & - & Tidak signifikan $(\mathrm{p}$-value $=0.200)$ \\
\hline
\end{tabular}

Tabel 4. Rekapitulasi Nilai Signifikansi Parameter Kelelahan

\begin{tabular}{|c|c|c|c|}
\hline \multirow[b]{2}{*}{ Parameter } & \multicolumn{3}{|c|}{ Nilai signifikansi } \\
\hline & $\begin{array}{l}\text { Selang interval } \\
\text { waktu }\end{array}$ & Usia & Waktu mengemudi \\
\hline RMSSD & 0.725 & 0.548 & 0.605 \\
\hline Rasio LF/HF & 0.518 & 0.648 & 0.080 \\
\hline VAS & 0.006 & 0.339 & 0.200 \\
\hline
\end{tabular}

\section{Kesimpulan}

Kelelahan dari sisi persepsi menunjukkan adanya peningkatan untuk kriteria selang interval waktu berkendara sementara kelelahan dari sisi fisiologis tidak menunjukkan hasil yang signifikan terhadap kriteria selang interval waktu berkendara, usia partisipan, dan waktu mengemudi. Beberapa peneliti menyatakan pengukuran dari sisi fisiologis dinyatakan lebih prediktif dan reliabel dalam mendeteksi kelelahan. Oleh karena itu, pengukuran dengan secara subjektif perlu di validasi lebih lanjut. Kuesioner VAS dan alat ukur Polar RS800CX berkorelasi positif dengan nilai signifikansi sebesar 0,025. Artinya, kedua alat ukur tersebut memiliki kekuatan yang sama dalam mendeteksi kelelahan pengemudi bus Damri. Melihat dari sisi kemudahan penggunaan kuisioner VAS lebih sedikit memakan waktu dibandingkan penggunaan alat ukur Polar RS800CX, sehingga penggunaan kuesioner VAS sangat dianjurkan.

Setengah dari set data pengemudi bus menunjukkan peningkatan kondisi kelelahan pada selang interval waktu berkendara 2 hingga 2,5 jam sehingga pemberlakuan jam istirahat pada waktu tertentu setiap selesai mengemudi selama 1 ritase sangat dianjurkan untuk meminimisasi peningkatan kondisi kelelahan. Pembagian jam kerja dari pihak Damri tidaklah berimbang, ditandai dengan waktu mengemudi pagi memiliki lama waktu sekitar 7 jam 30 menit sedangkan waktu mengemudi siang memiliki lama waktu 4 jam 30 menit (06.00-18.00). Kondisi tersebut memiliki potensi peningkatan kondisi kelelahan pada pengemudi. Sehingga sebaiknya pihak Damri mengkaji ulang pembagian waktu pengemudi dalam berkendara. 


\section{Daftar Pustaka}

Bridger, R.S. (2003). Introduction to Ergonomic $\left(2^{\text {nd }}\right.$ ed.). London and New York: Routledge.

Chen, C., Xie, Y. (2014). The impact of multiple rest-break periods on commercial truck driver's crash risk. Journal of safety research, 87-93.

Ferri, R., Curzi-Dascalova, L., Gracco, S.D., Elia, M., Musumeci, S.A., Pettinato, S. (1998). Heart Rate Variability and apnea during sleep in Down's syndrome. Journal Sleep Research Society, 7: 282-287.

Gustiadi, R. (2014). Rencana Strategis (Renstra) 2013-2018. Dinas Perhubungan Kota Bandung.

Hartono, T.L., Setiaji, F.D., Setyawan, I. (2013). Alat bantu analisis heart rate variability. Tehne Jurnal IImiah Elektronika, 12: 141-157.

Insana, S.P., Downs, H.E.M. (2010). Maternal postpartum sleepiness and fatigue: associations with objectively measured sleep variables. Journal of Psychosomatic Research, 69: 467-473.

Iridiastadi, H., Yassierli. (2014). Ergonomi suatu pengantar. Bandung: PT Remaja Rosdakarya.

Jhonson, L.C., Spinweber, C.L., Gomez, S.A. (1990). Benzodiazepines and cafferine: effect on daytime sleepiness, performance, and mood. Psychopharmacology, 101: 160167.

Ji, Q., Yang, X. (2002). Real-time eye, gaze, and face pose tracking for monitoring driver vigilance. Real-Time Imaging, 8: 357-377.

Korber, M., Cingel, A., Zimmermann, M., Bengler, K. (2015). Vigilance decrement and passive fatigue caused by monotony in automated driving. Procedia Manufacturing, 3: 2403-2409.

Lal, S.K.L, Craig, A. (2001). A critical review of the psychophysiology of driver fatigue. Biological Psychology, 55: 173-194.

Lal, S.K.L. (2001). The psychophysiology of driver fatigue/drowsiness: Electroencelophalography, electrooculogram, electrocardiogram and psychological effects.

Lee, K.A., Hicks, G., Murcia, G.N., Validity and Reliability of Scale to Assess Fatigue, Psychiatry Research, 36, 1990, pp. 291298.

Leung, A.W.S., Chan, C.C.G., He, J. (2004). Structural stability and reliability of swedish occupational fatigue inventory among chinese vdt worker. Applied Ergonomics, 35: 233-241.

Mahachandra, M., Yassierli, Sutalaksana, I.Z., Mahachandra, M., Yassierli, Sutalaksana, I.Z., Suryadi, K. (2012). Sensitivity of heart rate variability as indicator of driver's sleepiness. Network of Ergonomic Societies Conference (SEANES). Langkawi, Kedah.

Nurhasikin. (2013). Penduduk usia produktif dan ketenagakerjaan. Disadur dari: http://kepri.bkkbn.go.id/Lists/Artikel/DispFor m.aspx?ID=144.hmtl. 16 Maret 2016.

Nurmianto, Eko (1998). Ergonomi: Konsep Dasar dan Aplikasinya. Jakarta: Guna Widya.

Pastor, G., Tejero, P., Choliz, M., Roca, J. (2006). Rear-view mirror use, driver alertness and road type: An empirical study using EEG measures. Transportation Research Part F, 9: 286-297.

Patel, M., Lal, S.K.L., Kavanagh, D., Rossiter, P. (2011). Appliying neural network analysis on heart rate variability data to assess driver fatigue. Expert System of Aplications, 38: 7235-7242.

Philip, P., Sagaspe, P., Taillard, J. (2005). Fatigue, sleepiness, and performance in simulated versus real driving. Sleep. vol. 28, No. 12.

Rodahl, K. (2005). The Physiology of Work. UK, USA: Taylor \& Francis e-Library.

Schneider, C., Fulda, S., Schulz, H., Daytime Schneider, C., Fulda, S., Schulz, H. (2004). Daytime variation in performance and tiredness/sleepiness ratings in patients with insomnia, narcolepsy, sleep apnea and normal controls. Journal Sleep Research, 13: 373-383.

Sudjana (2004). Statistika untuk Ekonomi dan Niaga. Bandung: Transito.

Sutalaksana, I.Z., Anggawisastra, R., Jann, H.T. (1979). Teknik dan Tata Cara Kerja. Bandung: Departemen Teknik Industri ITB.

Williamson, A., Lombardi, D.A., Folkard, S., Stutts, J., Courtney, T.K., Connor, J.L. (2011). The link between fatigue and safety. Accident Analysis of Prevention, 43: 498515.

Zang, G., Yau, K.K.W., Zhang, X., Li, Y. (2016). Traffic accidents involving fatigue driving and their extent casualities. Accident Analysis of Prevention, 87: 34-42. 
